\title{
Analisis Kualitas Pertanyaan dan Penjelasan Siswa pada Materi Usaha dan Energi Kelas XI SMA Al-Azhar Palu
}

\author{
Dicky Aprianus Losi, Fihrin dan Jusman Mansyur \\ Dickyaprilio43@yahoo.com \\ Program Studi Pendidikan Fisika FKIP Universitas Tadulako \\ Jl. Soekarno Hatta Km. 9 Kampus Bumi Tadulako Tondo Palu - Sulawesi Tengah
}

\begin{abstract}
Abstrak - Penelitian ini bertujuan untuk menganalisis kemampuan siswa dalam membuat pertanyaan dan memberikan penjelasan terhadap pertanyaan pada materi Usaha dan Energi. Penelitian ini merupakan penelitian deskriptif-kualitatif dengan desain studi kasus. Subjek penelitian adalah siswa SMA Al-Azhar Palu Kelas XI berjumlah 26 orang, terpilih 6 orang sebagai responden. Berdasarkan hasil skor yang diperoleh dari data pertanyaan dan penjelasan yang dibuat oleh siswa, yang terbagi ke dalam tiga kategori yaitu kategori tinggi, sedang dan rendah. Hasil penelitian menunjukkan presentase pertanyaan berkategori tinggi sebesar $15,38 \%$, kategori sedang sebesar $73,08 \%$ dan kategori rendah sebesar $11,54 \%$, sedangkan presentase penjelasan berkategori tinggi sebesar $19,23 \%$, sedang sebesar $76,92 \%$ dan rendah sebesar $3,85 \%$. Hal ini menunjukkan bahwa siswa kelas XI SMA Al-Azhar Palu mampu membuat pertanyaan berkualitas tinggi yaitu Pertanyaan tersebut tentunya memenuhi kriteria yaitu jelas, benar, memerlukan lebih dari cara yang sederhana dalam menjawab dan memiliki solusi yang tepat beserta penjelasannya. Berdasarkan tingkatan taksonomi bloom menemukan bahwa $38,46 \%$ dari pertanyaan yang ada dikategorikan pertanyaan yang berkualitas tinggi.
\end{abstract}

Kata Kunci: kualitas pertanyaan, kualitas penjelasan, usaha dan energi

\section{PENDAHULUAN}

Proses pembelajaran sangat berperan penting untuk tercapainya tujuan pendidikan, karena selama proses pembelajaran berlangsung guru dapat melihat sejauh mana tingkat pemahaman yang diperoleh oleh siswa. Proses pembelajaran yang baik tentunya melibatkan kerjasama yang baik antara guru dan siswa.

Selama proses pembelajaran siswa akan banyak menemukan konsep dan rumus yang digunakan selama proses pembelajaran fisika berlangsung. Hal tersebut akan menimbulkan pertanyaan baru bagi siswa ketika siswa belum memahami tentang penjelasan guru. Pentingnya siswa bertanya di kelas mendorong terjadinya interaksi antar siswa agar siswa lebih terlibat secara pribadi dan lebih bertanggung jawab terhadap pertanyaan yang diajukan.

Selain itu, Partin mengungkapkan pentingnya penggunaan keterampilan bertanya siswa secara tepat adalah untuk mencapai tujuan yang diharapkan dalam suatu proses belajar mengajar di kelas, yaitu membangkitkan minat, rasa ingin tahu, dan memusatkan perhatian siswa terhadap suatu pokok bahasan atau konsep, mendiagnosis kesulitan-kesulitan khusus yang menghambat siswa belajar, memberikan kesempatan kepada siswa untuk mengkritisi suatu informasi yang ia dapatkan, mendorong siswa mengemukakan pendapatnya dalam diskusi, serta menguji dan mengukur hasil belajar siswa [1].

Penelitian yang dilakukan Galloway mengemukakan bahwa tahun pertama siswa mampu menghasilkan kualitas pertanyaan yang sangat tinggi beserta penjelasannya. Atas dasar batas minimum dari tingkat kognitif dan kualitas penjelasan, menemukan bahwa $75 \%$ dari pertanyaan yang ada dapat dikategorikan sebagai pertanyaan berkualitas tinggi. Pertanyaan tersebut tentunya memenuhi kriteria yaitu jelas, benar, memerlukan lebih dari cara yang sederhana dalam menjawab dan memiliki solusi yang tepat serta pengecoh yang masuk akal [2].

Penelitian yang dilakukan oleh Widjaya [3] menemukan bahwa teknik bertanya guru ketika melaksanakan proses pembelajaran mempunyai pengaruh terhadap pencapaian belajar dan cara berpikir siswa. Guru yang tidak memiliki kecakapan dalam mengajukan pertanyaan dan yang tidak mengajukan pertanyaan ketika mengajan akan kesulitan dalam mengarahkan proses pembelajaran. Bahkan sebaliknya, sebuah pertanyaan yang bagus akan memberikan pedoman dan bimbingan kepada siswa dalam membentuk jawaban atau tanggapan yang bermakna [3].

Berdasarkan penelitian yang dilakukan sebelumnya peneliti menemukan masih ada hal yang perlu dikaji lagi lebih mendalam mengenai pertanyaan dan penjelasan yang dihasilkan oleh siswa sehingga peneliti tertarik untuk 
melakukan penelitian mengenai kualitas pertanyaan dan penjelasan siswa pada materi usaha dan energi Kelas XI SMA Al-Azhar Palu.

Tujuan utama penelitian ini menitikberatkan pada gambaran kualitas pertanyaan yang dihasilkan oleh siswa berdasarkan tingkatan pada Taksonomi Bloom serta gambaran kualitas penjelasan siswa terkait dengan pertanyaanpertanyaan yang ada. Dalam hal kemampuan siswa dalam membuat pertanyaan dan memberikan penjelasan pada pertanyaan yang ada. Peneliti tidak melihat aspek paham dan tidak pahamnya dari responden pada materi tersebut. Peneliti hanya mengungkapkan dan mendeskripsikan dari segi kemampuan siswa dalam membuat pertanyaan berdasarkan tingkatan pada Taksonomi Bloom serta kemampuan siswa dalam memberikan penjelasan terhadap pertanyaan yang ada.

\section{METODE PENELITIAN}

Penelitian ini merupakan penelitian deskriptif-kualitatif. Subyek penelitian ini berjumlah 26 orang yang merupakan siswa kelas XI D SMA Al-Azhar Palu. Responden dalam penelitian ini berjumlah 6 orang siswa yang sedang mempelajari materi tentang Usaha dan Energi. Sebanyak 6 orang siswa selanjutnya terpilih untuk diwawancarai berdasarkan pengelompokkan tinggi, sedang dan rendah baik kualitas pertanyaan maupun penjelasan.

\section{HASIL DAN PEMBAHASAN}

\section{A. Hasil Penelitian}

\section{Kualitas Pertanyaan}

Kegiatan Penelitian dilakukan di SMA AlAzhar Palu pada siswa-siswi kelas XI. Perangkat instrumen yang digunakan dalam penelitian ini yaitu rubrik penilaian kualitas pertanyaan dan penjelasan siswa yang digunakan untuk menganalisis pertanyaan dan penjelasan yang dibuat oleh siswa.

Pengumpulan data dilakukan melalui nonparticipant observation yang merupakan penelitian yang dilakukan dengan cara tidak terjadinya interaksi secara langsung antara peneliti dengan responden.

Kegiatan pengumpulan pertanyaan dan penjelasan siswa dilakukan pada saat akhir bab pembelajaran mengenai materi Usaha dan Energi oleh guru penanggung jawab mata pelajaran fisika dengan memberikan arahan bahwa pengumpulan pertanyaan dan penjelasan siswa ini termasuk ke dalam bentuk penilaian sumatif dan telah disampaikan 2 minggu sebelum dilakukannya pengumpulan pertanyaan serta penjelasan dari pertanyaan tersebut. Penentuan responden ini diperoleh dari hasil penilaian pada kualitas pertanyaan dan penjelasan yang dibuat oleh siswa yang dibagi menjadi tiga kategori dalam kelompok yaitu kategori tinggi, sedang dan rendah. Kemudian dari ketiga kategori tersebut dipilih 6 orang sebagai responden untuk diwawancarai berdasarkan skor perolehan siswa.

Hasil perolehan skor kualitas pertanyaan yang dihasilkan oleh masing-masing subjek terlihat sudah baik dan selanjutnya dari 26 subjek akan dipilih 3 responden untuk dilakukan wawancara secara mendalam. Berikut ini merupakan contoh pertanyaan yang dihasilkan oleh responden

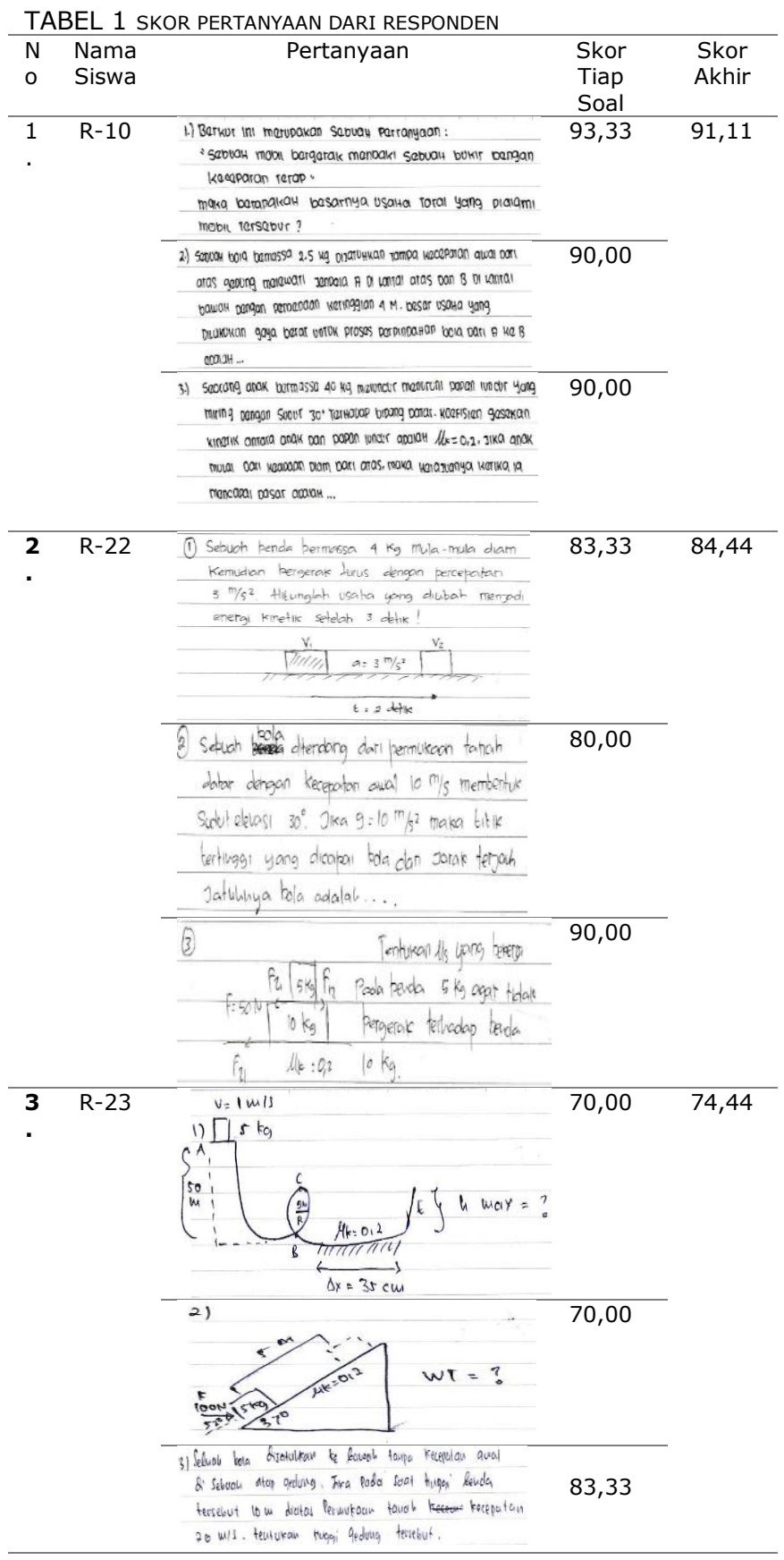


p-ISSN 2338-3240, e-ISSN 2580-5924

Jumlah pertanyaan keseluruhan dihasilkan siswa berjumlah 78 pertanyaan dengan presentase pertanyaan berdasarkan tingkatan kategori taksonomi bloom dapat dilihat pada gambar berikut :

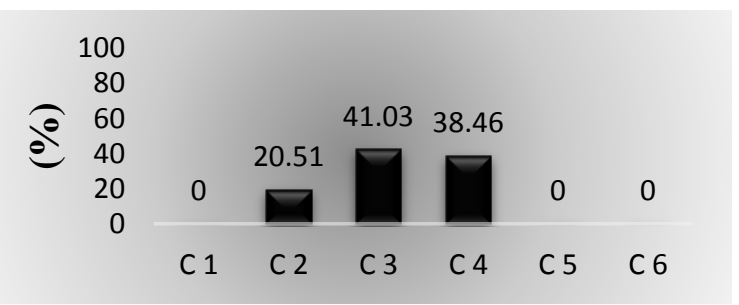

Gbr 1. Presentase kategori tingkat rata-rata perseentase kualitas pertanyaan berdasarkan tingkatan Taksonomi Bloom

Berdasarkan gambar presentase di atas terlihat hanya sebagian kecil pertanyaan yang termasuk pada kategori rendah pada taksonomi bloom (kurang dari 15 siswa) dan mayoritas pertanyaan yang dihasilkan terletak pada kategori level ketiga yang membutuhkan analisis dalam bentuk masalah perhitungan yang melibatkan satu atau beberapa tahapan perhitungan dalam penyelesaian.

$>$ Kualitas Penjelasan

Skor kualitas penjelasan dari kumpulan sampel penjelasan subjek berdasarkan skor pada rubrik dapat dilihat pada Gambar 2.

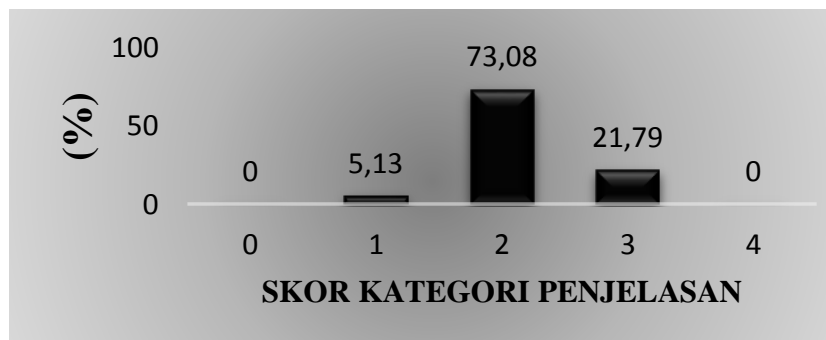

Gbr 2. Diagram kategori tingkat rata-rata perseentase kualitas penjelasan berdasarkan rubric

Berdasarkan Gambar 2 dapat dilihat sebagian besar penjelasan yang diberikan siswa terkait dengan pertanyaan yang ada sudah cukup baik hanya saja masih terdapat 5,13\% siswa yang menjawab salah tetapi sedikit menyinggung sedangkan yang termasuk ke dalam kategori keempat pada penjelasan terdapat $0 \%$ yang artinya belum terdapat siswa yang mampu memberikan penjelasan ke tahapan yang mengandung pernyataan atau jawaban yang tepat masuk akal dan disertai strategi solusi fisika dalam pemecahan masalah.

Berdasarkan hasil analisa kualitas pertanyaan dan penjelasan siswa maka diperoleh data kuantitatif dari nilai yang diperoleh pada penilaian menggunakan rubrik pertanyaan dan penjelasan, dapat dilihat pada Tabel 1:

TABEL 1. PRESENTASI KUALITAS PERTANYAAN DAN PENJELASAN SUBJEK

\begin{tabular}{|c|c|c|c|c|c|}
\hline \multicolumn{3}{|c|}{ Kualitas Pertanyaan (\%) } & \multicolumn{3}{c|}{ Kualitas Penjelasan (\%) } \\
\hline Tinggi & Sedang & Rendah & Tinggi & Sedang & Rendah \\
\hline 15,38 & 73,08 & 11,54 & 19,23 & 76,92 & 3,85 \\
\hline
\end{tabular}

\section{B. Pembahasan}

Pertanyaan yang dianalisis merupakan pertanyaan siswa yang dibuat secara tertulis berbeda dengan penelitian yang dilakukan oleh Hanifah yang melihat kualitas pertanyaan yang diajukan siswa selama proses pembelajaran [4]. Penelitian yang dilakukan Hanifah $d k k$ dominan pertanyaan yang mampu diajukan oleh siswa berada pada kategori C2 sebanyak 50 pertanyaan, berbeda dengan hasil yang diperoleh oleh peneliti yang menemukan hanya terdapat 14 pertanyaan yang berada pada kategori C2. Berdasarkan perbandingan tersebut terlihat bahwa kemampuan siswa dalam membuat pertanyaan lebih tinggi jika dilakukan secara tertulis dibanding secara lisan. Hal ini sesuai dengan yang diungkapkan oleh Widodo bahwa siswa sedikit mengajukan pertanyaan secara lisan, namun setelah diberikan kesempatan untuk menuliskan pertanyaan-pertanyaan mereka, ternyata siswa bisa memunculkan banyak sekali pertanyaan [5]. Selain itu hampir sebagian besar pertanyaan yang ada disertai dengan penjelasan yang baik. Namun bagi beberapa siswa membuat pertanyaan merupakan hal yang asing untuk dilakukan karena selama ini proses pembelajaran yang berlangsung hanya melibatkan siswa dalam hal menjawab pertanyaan yang diberikan oleh guru.

Pada rubrik penilaian kualitas pertanyaan yang digunakan terdapat delapan aspek yang dinilai pada pertanyaan dengan rentang skor penilaian dari satu sampai empat. Untuk skor satu aspek yang dinilai dianggap sangat kurang, skor dua dianggap cukup, skor tiga kategori baik, sedangkan skor empat kategori sangat baik. Aspek pertama yang dinilai mengenai kalimat yang digunakan pada pertanyaan termasuk ke dalam kalimat yang singkat dan jelas atau tidak. Aspek kedua yang dinilai merupakan tujuan yang disampaikan oleh pertanyaan dapat dimengerti oleh penjawab atau tidak dimengerti oleh penjawab. Aspek ketiga yang dinilai merupakan penyajian masalah pada pertanyaan apakah masalah yang disajikan oleh pertanyaan hanya terdapat satu masalah atau lebih dari satu masalah. Aspek keempat yang dinilai pertanyaan yang dibuat dapat menghasilkan jawaban yang 
bukan sekedar ya atau tidak tetapi menghasilkan jawaban yang memiliki proses atau cara pemecahan masalahnya. Aspek kelima yang dinilai merupakan bahasa yang digunakan dalam pertanyaan tersebut menggunakan bahasa yang dikenal baik oleh penjawab. Aspek keenam yang dinilai pada pertanyaan mengenai ada dan tidaknya pertanyaan atau masalah yang menimbulkan tafsiran ganda. Sedangkan, aspek ketujuh yang dinilai berdasarkan kategori pertanyaan yang dihasilkan termasuk ke dalam kategori pada tingkatan taksnomi bloom.

Berdasarkan hasil analisis kualitas pertanyaan siswa terlihat distribusi pertanyaan tersebar hampir semua ketingkatan taksonomi, dengan hampir sebagian besar pertanyaan yang dihasilkan terletak pada kategori aplikasi dan analisis. Hal ini disebabkan guru yang mengajar dikelas tersebut pada saat proses pembelajaran cenderung membiasakan siswa pada pertanyaan-pertanyaan tingkat tinggi selain itu penyampaian kepada siswa bahwa pertanyaan yang mereka buat nantinya termasuk ke dalam penilaian sumatif, hal itulah yang lebih menekankan pada siswa untuk membuat pertanyaan yang baik dan masuk akal. Cara demikian terbukti mampu melatih siswa untuk lebih berpikir dan memahami materi yang akan diajarkan. Hal ini sejalan dengan yang diungkapkan oleh Dillon dalam Widodo yang berpendapat bahwa siswalah yang harus banyak bertanya sebab siswalah yang sesungguhnya belajar [5]. Dengan bertanya sesungguhnya siswa didorong untuk berpikir.

Namun, hal ini berbeda dengan hasil penelitian yang diungkapkan oleh Widodo yang menyatakan pada hasil penelitian yang diperolehnya belum terdapat siswa yang mampu membuat pertanyaan pada kategori C3 dan C4 akan tetapi di dominasi pada pertanyaan kategori $\mathrm{C} 1$ dan $\mathrm{C} 2$. Hal ini di akibatkan guru pada proses pembelajaran mengajukan pertanyaan hanya seputar pada jenjang kognitif tingkat rendah (hafalan dan pemahaman) dan tidak membiasakan siswa pada pertanyaan-pertanyaan tingkat tinggi, serta banyaknya pertanyaan yang diajukan guru yang hanya berkaitan dengan teknis pembelajaran secara umum dan bukan untuk pembahasan konsep/materi [5].

Berdasarkan Tabel 1 menunjukkan bahwa rata-rata presentase siswa yang memiliki kualitas pertanyaan dan penjelasan yang tinggi merupakan siswa yang berada pada kategori sedang dengan presentasi pertanyaan sebesar $73,08 \%$ dan presentasi untuk penjelasan sebesar $76,92 \%$. Presentase ini menyatakan bahwa mayoritas kemampuan siswa dalam hal membuat serta memberi penjelasan akan pertanyaan sudah cukup baik bila dibandingkan dengan jumlah presentase siswa untuk pertanyaan kategori rendah yaitu sebesar $11,54 \%$ dan $3,85 \%$ untuk penjelasan.

Penelitian ini sebelumnya telah di lakukan oleh Galloway dkk di Universitas besar di Inggris pada dua tahun berbeda. Penelitian yang dilakukan hampir sama dengan penelitian yang peneliti lakukan yaitu menilai tentang kualitas pertanyaan dan penjelasan yang dihasilkan siswa hanya saja untuk penelitian yang dilakukan oleh Galloway $d k k$ membutuhkan waktu yang lama karena dilakukan di dua tahun berbeda yaitu di tahun 2010 dan tahun 2011 selain itu, penelitian yang dilakukan oleh Galloway $d k k$ menggunakan aplikasi web yaitu PeerWise. Penggunaan PeerWise sudah ada beberapa peneliti yang menerapkan di Indonesia dan memberikan dampak positif bagi subjek penelitiannya namun untuk di daerah Palu penggunaan aplikasi PeerWise belum dikenal dan masih perlu diadakan sosialisasi terlebih dahulu tentang penggunaan aplikasi tersebut bagi guru dan bagi siswa sehingga peneliti mendapatkan satu cara agar tetap bisa menganalisis pertanyaan dan penjelasan siswa tanpa menggunakan PeerWise yaitu dengan cara meenyuruh siswa membuat tiga pertanyaan dan menjawab satu pertanyaan yang dibuatnya yang di anggap paling susah sedangkan dua pertanyaan lainnya di jawab oleh siswa lainnya secara acak [2].

Perbedaan pada penelitian yang dilakukan oleh Galloway [2], (dengan yang peneliti) lakukan tidak berdampak pada hasil penelitian yang didapatkan. Hasil penelitian yang diperoleh oleh peneliti menunjukkan kualitas pertanyaan yang baik yaitu tingkatan pertanyaannya berada pada C2, C3 bahkan C4 pada tingkatan taksonomi bloom sedangkan untuk kualitas penjelasannya hampir semua siswa mampu menjawab pertanyaan yang diberikan dengan tepat dan jelas.

\section{KESIMPULAN DAN SARAN}

\section{A. Kesimpulan}

Berdasarkan hasil penelitian menunjukkan bahwa siswa kelas XI D SMA Al-Azhar Palu mampu membuat pertanyaan berkualitas tinggi beserta penjelasannya. Berdasarkan tingkatan taksonomi bloom menemukan bahwa 42,31\% yang berada pada tingkatan C3 dan $38,46 \%$ yang berada pada C4 sehingga pertanyaan yang ada dikategorikan ke dalam pertanyaan yang berkualitas tinggi. Pertanyaan tersebut tentunya memenuhi kriteria yaitu jelas, benar, 
memerlukan lebih dari cara yang sederhana dalam menjawab dan memiliki solusi yang tepat. Sedangkan, untuk kualitas penjelasan tergolong sudah cukup baik karena mayoritas sudah bisa menjawab pertanyaan dengan benar namun belum disertai dengan kalimat penjelasan yang baik yang terlihat dengan peroleh presentase sebesar 71,80 \%.

B. Saran

Berdasarkan kesimpulan di atas maka saran yang diberikan pada penelitian ini adalah:

1. Berdasarkan kemampuan siswa dalam membuat pertanyaan berkualitas tinggi beserta penjelasannya diharapkan dapat menjadi acuan bagi para guru dalam mengembangkan pertanyaan siswa serta mempertimbangkan model dan metode yang digunakan dalam pengajaran.

2. Guru diharapkan dalam menjelaskan konsep fisika khususnya konsep Usaha dan Energi tidak hanya berfokus dalam persoalan matematis, namun harus menjelaskan konsep secara fisis dan mengaitkan konsep fisika dengan fenomena-fenomena dalam kehidupan sehari-hari, agar siswa mampu
p-ISSN 2338-3240, e-ISSN 2580-5924

membuat pertanyaan yang berkaitan dengan konsep.

3. Guru diharapkan lebih meningkatkan kemampuannya dalam hal memberikan pertanyaan-pertanyaan pada proses pembelajaran berlangsung.

\section{DAFTAR PUSTAKA}

[1] R.L. Partin. Kiat Nyaman Mengajar di Dalam Kelas Edisi Kedua. Jakarta: Indeks, 2009.

[2] K. R. Galloway, J. Riise, dan D. Homer. "Assesing the quality of student-generated question repository". Physical Review Special Topics-Physics Education Resers. 10,020105, 2014.

[3] H. Widjaya, I. N. L. Segep, I. B. Suandi, dan Putrayasa. "Analisis pertanyaan guru dalam proses pembelajaran bahasa indonesia pada siswa kelas $v$ sekolah dasar Negeri 3 Selong Lombok Timur Nusa tenggara barat tahun pembelajaran 2012/2013". eJournal Program Pascasarjana Universitas Pendidikan Ganesha Program Studi Pendidikan Bahasa dan Sastra Indonesia, 2013.

[4] H. Hanni, D. Sikumbang, dan B. Yolida. "Hubungan Antara Kualitas Pertanyaan Siswa Berdasarkan Taksonomi Bloom Dengan Hasil Belajar Siswa". Skripsi, Universitas Lampung, 2014.

[5] A. Widodo. "Profil pertanyaan guru dan siswa dalam pembelajaran sains". Jurnal Pendidikan dan Pembelajaran, vol. 4, no. 2, pp. 139-14, 2006. 